\title{
Immunohistochemical Study of Aquaporin 1 and 2 in the Reproductive Tract of the Bactrian camel (Camelus bactrianus)
}

\author{
Estudio Inmunohistoquímico de Acuaporina 1 y 2 en el \\ Tracto Reproductivo del Camello Bactriano (Camelus bactrianus)
}

\author{
Fengli An* \& Jianlin Wang**
}

\begin{abstract}
AN, F. \& WANG, J. Immunohistochemical study of aquaporin 1 and 2 in the reproductive tract of the Bactrian camel (Camelus bactrianus). Int. J. Morphol., 34(4):1218-1222, 2016.

SUMMARY: Spermatogenesis is associated with considerable fluid secretion or absorption in the male reproductive tract. Aquaporins (AQPs) are membrane protein channels that allow the rapid movement of water through epithelium. In the present study, immunohistochemistry was utilized to localize the expression of AQP 1, AQP2 in the testis and prostate of adult bactrian camel (Camelus bactrianus). Results show that AQP1 have intense reaction in rete testis, efferent ducts, vessels, seminiferous duct and in the prostate, AQP2 was found minor expression in the rete testis, vessels and prostate, which suggesting that AQP1 may have the main role in the absorption of the large amount of testicular fluid in male camel reproductive tract. Investigations of AQPs biology in camel could be relevant with technologies for assisted procreation in animal husbandry and aquaculture.
\end{abstract}

KEY WORDS: Aquaporin1; Aquaporin2; Immunohistochemistry; Bactrian Camel.

\section{INTRODUCTION}

It has been well accepted that the transport of water was due to simple diffusion through the lipid bilayer until the aquaporins (AQPs) were found (Gomes et al., 2009). Different AQPs have specific tissue distribution and execute particular physiological functions. In reproduction system, significant water movements take place throughout the duct. Male AQP1 knockout mice seem to have a reduced reproductive capacity (Oliveira et al., 2005). Otherwise, $\mathrm{AQP} 1$ was found expressed in the rete testis of adult mice (Lu et al., 2008), in the goose testis (Skowronski et al., 2010), in canine spermatozoa as well as the testis (Ito et al., 2008) and even in human testis (Yeung et al., 2010). AQP1 and 2 are expressed in efferent ducts of adult dogs (Domeniconi et al., 2008), in male genital tract of domestic cat (Arrighi \& Aralla, 2014). All this shows the complexity of AQP channels in genital system and suggests AQP1, 2 might serve an important role in animal reproduction.

Two-humped camel play vital socio-economic roles in severe drought areas, but this breed is in danger because of its low mating efficiency (Abdel Rahim, 1997), probably due to abnormal spermatozoal concentrations and motility variables (El-Harairy \& Attia, 2010). Male reproductive tract have active water transportation and secretion, rats with reduced reabsorption of fluid in reproductive tract have been shown subfertile or infertile (Alves et al., 2015). So fluid secretion or absorption in male reproductive tract are a prerequisite for luminal environment and normal spermatogenesis, but the genetic strategies is absent from camel confronting water shortage. Therefore, the present study was carried out to investigate the expression of AQP1 and 2 in the reproduction tract of Two-humped camel, which may provide basic data for water transportation during spermatogenesis in camels during severe drought periods.

\section{MATERIAL AND METHOD}

Animals and tissues preparation. The present study was carried out on five male Bactrian camels, aged 5-6 years and randomly selected from WuWei, GanSu Province, Chi-

\footnotetext{
* School of Pharmacy.

** School of Life Science, Lanzhou University, Lanzhou 730000, Gansu, China.
} 
na. All samples were obtained from animals during November to December in a local abattoir. Testes and prostates were fixed with $4 \%$ paraformaldehyde for no less than $24 \mathrm{~h}$, then tissues were thoroughly washed in PBS, dehydrated in graded ethanol and embedded in paraffin. Five micrometer-thick sections were cut from each tissue.

Immunohistochemistry. Tissue sections were deparaffinized in xylene, washed in alcohol and rehydrated in PBS. Antigen retrieval was performed in a microwave oven in 0.01M PBS (pH 7.4) for $15 \mathrm{~min}$, then the sections were cooled at room temperature and washed again in PBS. Endogenous peroxidase was blocked by using $3 \%$ hydrogen peroxide for $30 \mathrm{~min}$. After washing in PBS for three times, the goat serum (10\%) was used for 20 min to avoid any non-specific reactions. Then, the primary antibody, polyclonal rabbit anti-AQP1 was applied (sigma, dilution 1:500) and incubated in a moist chamber 4 overnight. Sections were incubated with biotin-labeled secondary antibodies and avidin-HRP third antibodies, positive staining was detected using DAB. The sections were counterstained with hematoxylin. Negative control sections have the same procedure except omitting primary antibody.

Analysis. A light microscopy was utilized for the histology studies of the sections (Zeiss, Germany), and photo-icrographs were recorded with a digital camera.

\section{RESULTS}

Histologically, the camel testis was organized into two compartments; seminiferous tubules and the surrounding interstitial tissue (Fig. 1A). The seminiferous tubule was externally enclosed with a basal lamina and several layers of myoid cells. Internally, the seminiferous epithelium consisted of: spermatogonia resting directly on the tubular basal lamina, intermediate spermatocytes, and luminal spermatids and spermatozoa (Fig. 1B). Camel prostate was composed of glandular alveolus and stroma. Epithelial basal cells formed an incomplete boundary layer. The basal cells

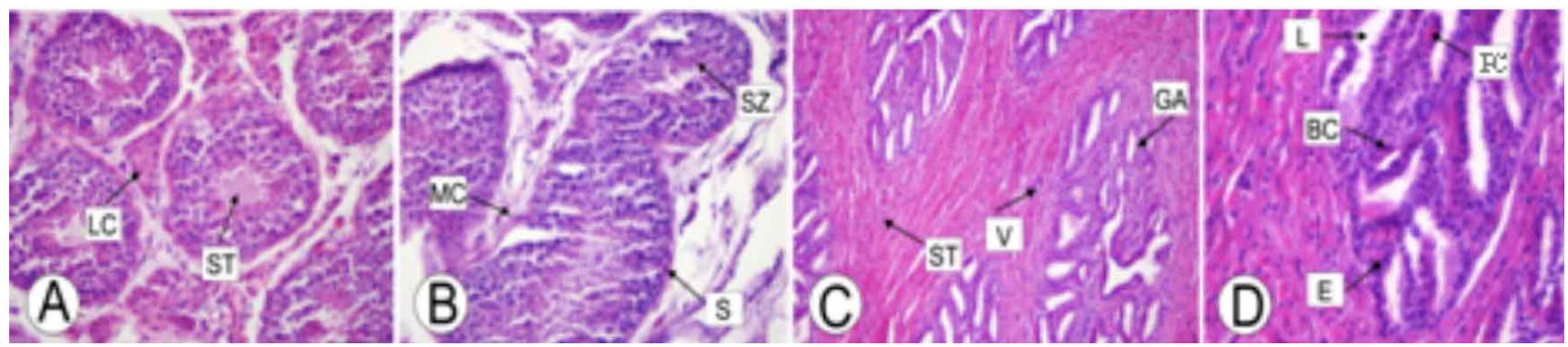

Fig.1. Microstructure of testis and prostate tissue of Bactrian camel, stained with hematoxylin and eosin. (A, B) view of camel testis shows the seminiferous tubules (ST), Interstitial endocrine cell (LC), spermatogonia (S), spermatozoid (SZ) and muscle-like cell around seminiferous tube (MC), (C-D) prostate gland: lumen of glandular alveolus (L), basal cells (BC), epithelial cells (E), stroma (ST), prostatic concretion (PC), glandular alveolus (GA).
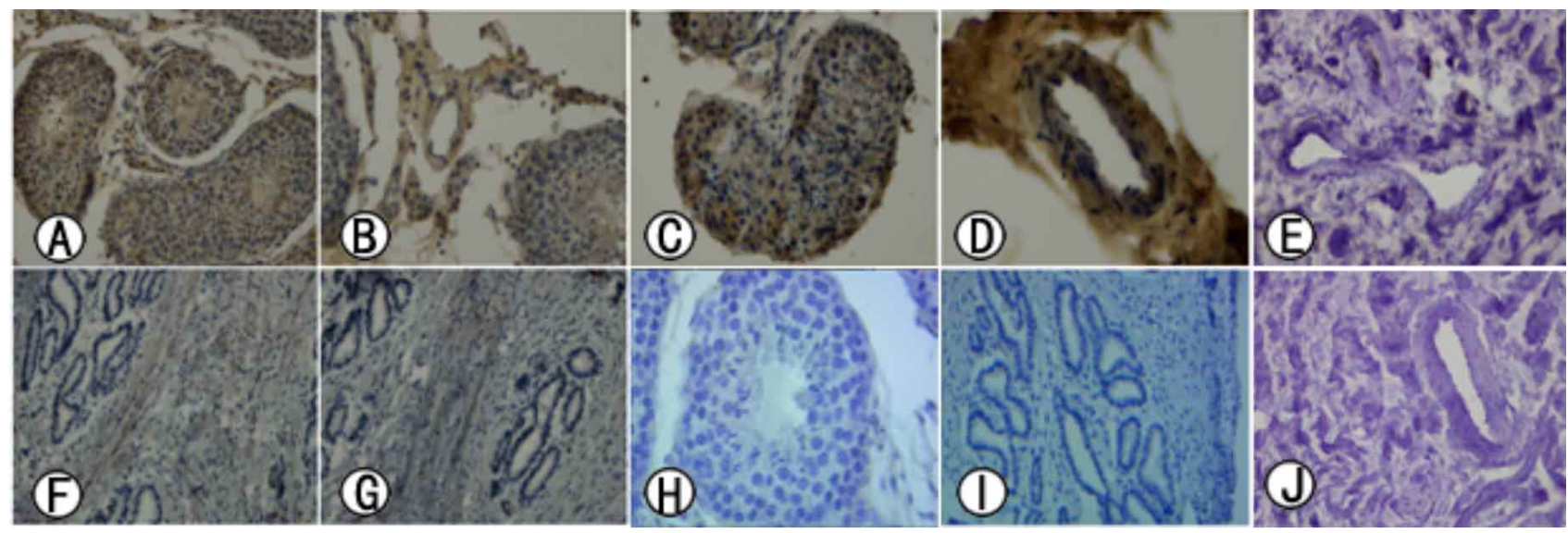

Fig. 2. Immunohistochemistry of AQP1 in testis and prostate tissue of Bactrian camel. (A)-(B) immunostaining for AQP-1 on the cuboidal epithelial cells in testis (arrows). (C) AQP1 expression in the capillary and venules. (D) AQP1 expression in seminiferous duct (E) - (I) Localization of AQP1 in the prostate. (J)- (L) the negative control of testis, efferent duct and prostate gland, in which primary antibodies were omitted. 


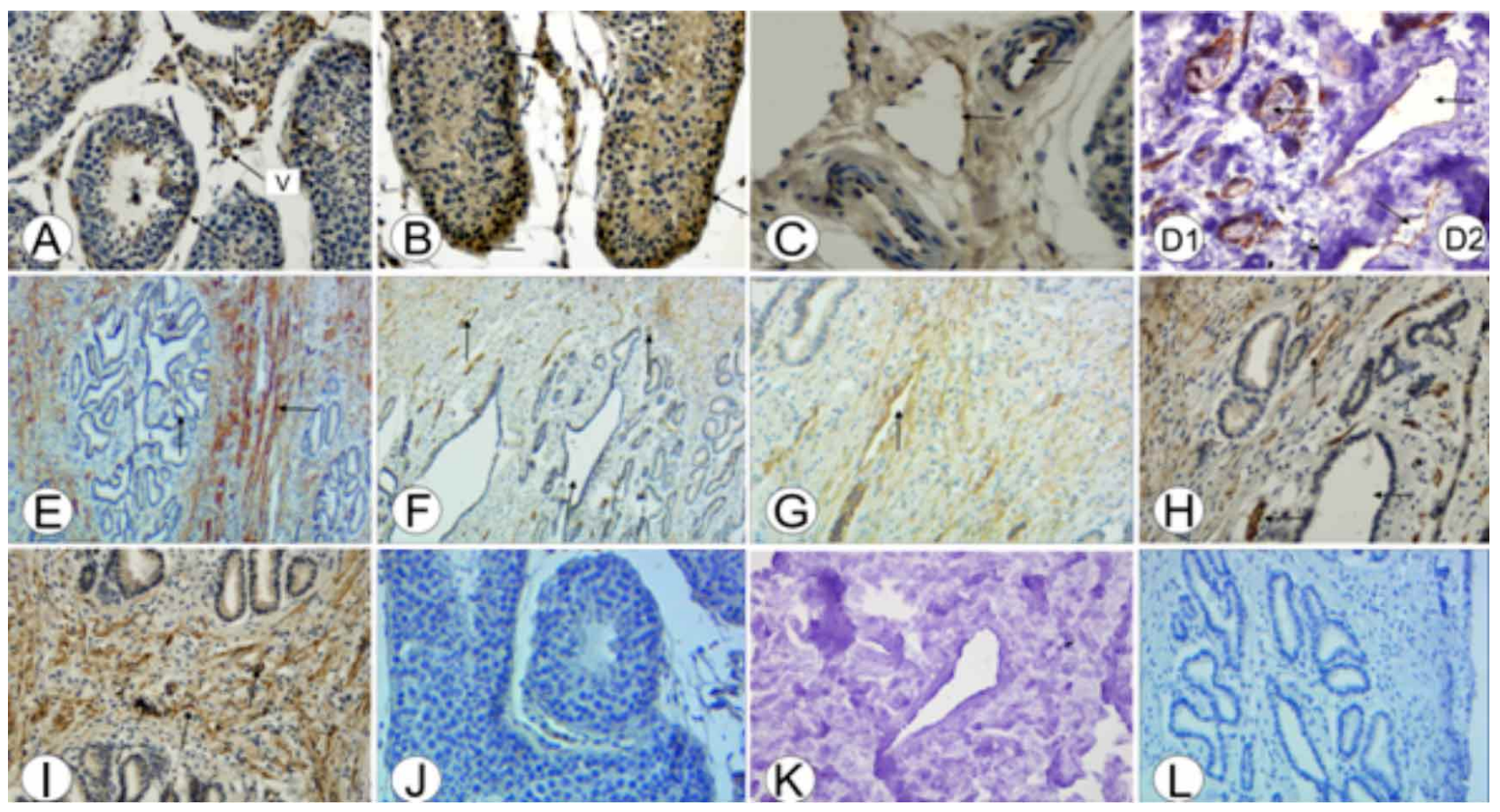

Fig. 3. Immunohistochemistry of AQP2 in testis and prostate tissue of Bactrian camel. (A)-(C) immunostaining for AQP2 on the cuboidal epithelial cells in testis (arrows). (D) AQP2 expression in the capillary and venules. (E)AQP2 expression in seminiferous duct (F-G) Localization of AQP2 in the prostate. $(\mathrm{H})-(\mathrm{J})$ negative control of testis, prostate and efferent duct, in which primary antibodies were omitted.

are a sporadic finding in camel prostate ductal epithelium. Secretory-like granules were observed in the cytoplasm of basal cells (Figs. 1C and 1D).

AQP1 immunoreactivity was found in both the testis and prostate. Strong immunostaining for AQP-1 were on the epithelial cells of rete testis (Fig. 2A). Positive reaction was also found in spermatogenic cells and sertoli cells lining the seminiferous epithelium (Fig. 2B). AQP-1 was localized on microvessels, vascular endothelial cells of the testicular interstitium (Fig. 2C). AQP1 protein is present in the seminiferous duct (Fig. 2D). Cells of the prostate glands showed a faint cytoplasmic AQP1 immunoreactivity. Positive AQP-1 immunoreaction depicted in cell membrane of venular endothelial cells and AQP-1 immunocytochemistry showed diffuse staining of basal cells, epithelial cells and stroma without expression in glandular alveolus (Fig. 2E-I). The control group of testis, prostate, in which primary antibodies were omitted, showed no positive results (Fig. 2J-L).

AQP2 showed minor diffuse positive reaction in rete testis epithelium (Fig. 3A, B), testicular efferent ducts (Fig. 3C) and in the capillary and venules (Fig. 3D). No reaction was detected in the vas deferens (Fig. 3E). A moderate reaction was localized in the prostate (Fig. 3F, G). The negative immunohistochemical controls performed without primary antibodies showed no positive reaction (Fig. 3H-J).

\section{DISCUSSION}

Rete testis is the initial segment of the male reproductive tract. It is postulated that the rete testis alters the nature of the fluid produced by the seminiferous tubules, producing more homogeneous sperm (Sellars \& Sidhu, 2001). The Bactrian camel testis is composed of seminiferous tubule and the surrounding interstitial tissue. There were spermatogonia, intermediate spermatocytes and spermatozoa internally. Stromal cells have group distribution with abundant blood vessels. Accidentally, a stromal cell with dual-core was seen in camel testis, maybe it's the active stage for spermatogenesis (Hafez \& Hafez, 2001). There was not only tight junction, desmosomes connection but also blood testosterone barrier in Bactrian camel testis, these are all conducive to the species resistance when under water deprivation and high temperature.

Drinking in the desert is affected by a number of factors, they must evolve to adapt to quick absorbtion when water is in supply. Camel can tolerate a loss of water corresponding to $30 \%$ of its body weight when dehydrated (Etzion et al., 1984), one of the most affected organ is reproductive tract. Because of the existence in male reproduction tract, testicular AQP1 and 2 can be considered as integral membrane proteins acting to maintain normal fluid 
in testis and prostate. In the present study, we found the presence of $\mathrm{AQP} 1$ and $\mathrm{AQP} 2$ in the testis and prostate of the adult Bactrian camel, the expression of this two AQPs were different in cell type and structure. Immunostaining for AQP1 on the cuboidal epithelial cells spermatogenic cells and sertoli cells in testis may relate to the crucial and exclusive role in water transport for the forming of rete testis fluid and sperm transit, because AQP-1 knockout mice showed histological changes with a slight dilatation of the rete testis lumen due to the obstruction of water reabsorption occurred (Zhou et al., 2001). AQP2 showed diffuse minor reaction in rete testis epithelium and testicular efferent ducts. AQPs are not only water selective, but also permeable to water and other uncharged molecules (Herrera \& Garvin, 2011). Maybe AQP1 is the major water-specific channel and AQP2 plays an important role in the water reabsorption. Vascular endothelial cells belong to simple squamous epithelium, acting as a barrier for blood and tissue exchanging. Endothelial cells under normal physiological condition can selectively allow small molecule through the vessel wall. AQP1 and 2 expression in the capillary and venules of testis may responsible for the rapid absorption of the large amount of testicular fluid, thus inevitably influence nutrition supply and hormone transport for camels.

Camel prostates have tall secretory epithelial cells and basal cell in secretory acini, they both were characterized by rounded nuclei (Aly et al., 1991; Ali Abdullahi et al., 2012). Prostatic secretion of prostate fluid is one of the important components of semen, provide nutrients and the suitable environment for sperm. An intense reaction of AQP1 and a moderate reaction of AQP2 were localized in the prostate, shows that the water channel protein is closely related to the function, may be by influencing the moisture absorption liquid secretion, and transportation of sperm and nutrition, in facilitating the development and mature of the male reproductive organs may play an important role. They could also influence the production of fluid, which provides the physiological medium for further sperm development and maturation. AQP1 may have crucial role during water secretion into the seminal and prostatic fluid and remove water from intertubular space to maintain water equilibrium in the reproductive tract.

The vas deferens also have the ability to modify its luminal environment other than simply transit spermatozoa (Da Silva et al., 2006). The appearance of AQP1 in the camel vas deferens and no reaction of AQP2 there, indicates that vas deferens may be less water permeable. In the desert, animals could acquire water from mobilized body storage when they encounter water shortage, which can compensate for obligatory water loss (Takei et al., 2012). Camel also has an extraordinary capacity to survive without water supply. This is may be due to its ability to alter water homeostasis when under water deprivation. AQP1 probably participates in the regulation of water balance to maintain an appropriate luminal environment in which sperm can continue their maturation.

Distribution of AQP1 and AQP2 in the reproduction duct of camel was similar to laboratory animals (Pannabecker, 2015), suggesting that they play constitutive role in maintaining water balance, promoting sperm maturation and so on. Although further studies are required, our data may contribute to technological interest for camel assisted procreation, as they have the ability to allow water or solutes move across the plasma membrane during the process of freezing/thawing gametes and embryos.

\section{ACKNOWLEDGMENTS}

This work was financially supported by the Fundamental Research Funds for the Central Universities (862103).

AN, F. \& WANG, J. Estudio inmunohistoquímico de acuaporina 1 y 2 en el tracto reproductivo del camello bactriano (Camelus bactrianus). Int. J. Morphol., 34(4):1218-1222, 2016.

RESUMEN: La espermatogénesis se asocia con la secreción de una cantidad considerable de líquido o absorción en el tracto reproductor masculino. Las acuaporinas (ACPs) son canales de proteínas de membrana que permiten el movimiento rápido de agua a través del epitelio. En el presente estudio, se utilizó inmunohistoquímica para localizar la expresión de ACP 1, ACP2 en el testículo y la próstata del camello bactriano adulto (Camelus bactrianus). Los resultados muestran que ACP1 tiene una reacción intensa en la rete testis, conductos eferentes, vasos, conductos seminíferos y en la próstata. La expresión ACP2, de menor importancia, se observó en la rete testis, vasos y próstata, lo que sugiere que ACP1 puede tener el papel principal en la absorción de gran cantidad de líquido testicular en el tracto reproductivo masculino del camello. Las investigaciones de la biología del ACP en camello podrían ser relevantes para las tecnologías de reproducción asistida de la ganadería y la acuicultura.

PALABRAS CLAVE: Acuaporina 1; Acuaporina 2; Inmunohistoquímica; Camello Bactriano. 


\section{REFERENCES}

Abdel Rahim, S. E. Studies on the age of puberty of male camels (Camelus dromedaries) in Saudi Arabia. Vet. J., 154(1):79$83,1997$.

Ali Abdullahi, I.; Al-Hassan Musa, H. \& Jibril, A. Scrotal circumference and testicular morphometric characteristics of the camel (Camelus dromedarius) in the semi-arid environment of northern Nigeria. Int. J. Morphol., 30(4):1369-72, 2012.

Alves, M. G.; Sá, R.; Jesus, T. T.; Sousa, M. \& Oliveira, P. F. CFTR regulation of aquaporin-mediated water transport: A target in male fertility. Curr. Drug Targets, 16(9):993-1006, 2015.

Aly, A. E.; Abdo, M. S. \& Khabir, A. The fine structure of the camel prostate gland. Anat. Anz., 172(3):223-9, 1991.

Arrighi, S. \& Aralla, M. Immunolocalization of aquaporin water channels in the domestic cat male genital tract. Reprod. Domest. Anim., 49(1):17-26, 2014.

Da Silva, N.; Silberstein, C.; Beaulieu, V.; Piétrement, C.; Van Hoek, A. N.; Brown, D. \& Breton, S. Postnatal expression of aquaporins in epithelial cells of the rat epididymis. Biol. Reprod., 74(2):427-38, 2006.

Domeniconi, R. F.; Orsi, A. M.; Justulin, L. A. Jr.; Leme Beu, C. C. \& Felisbino, S. L. Immunolocalization of aquaporins 1, 2 and 7 in rete testis, efferent ducts, epididymis and vas deferens of adult dog. Cell Tissue Res., 332(2):329-35, 2008.

El-Harairy, M. A. \& Attia, K. A. Effect of age, pubertal stage and season on testosterone concentration in male dromedary camel. Saudi J. Biol. Sci., 17(3):227-30, 2010.

Etzion, Z.; Meyerstein, N. \& Yagil, R. Tritiated water metabolism during dehydration and rehydration in the camel. J. Appl. Physiol. Respir. Environ. Exerc. Physiol., 56(1):217-20, 1984.

Gomes, D.; Agasse, A.; Thiébaud, P.; Delrot, S.; Gerós, H. \& Chaumont, F. Aquaporins are multifunctional water and solute transporters highly divergent in living organisms. Biochim. Biophys. Acta, 1788(6):1213-28, 2009.

Hafez, E. S. \& Hafez, B. Reproductive parameters of male dromedary and bactrian camels. Arch. Androl., 46(2):85-98, 2001.

Herrera, M. \& Garvin, J. L. Aquaporins as gas channels. Pflugers Arch., 462(4):623-30, 2011.

Ito, J.; Kawabe, M.; Ochiai, H.; Suzukamo, C.; Harada, M.; Mitsugi, Y.; Seita, Y. \& Kashiwazaki, N. Expression and immunodetection of aquaporin 1 (AQP1) in canine spermatozoa. Cryobiology, 57(3):312-4, 2008.
Lu, D. Y.; Li, Y.; Bi, Z. W.; Yu, H. M. \& Li, X. J. Expression and immunohistochemical localization of aquaporin-1 in male reproductive organs of the mouse. Anat. Histol. Embryol., 37(1):1-8, 2008.

Oliveira, C. A.; Carnes, K.; França, L. R.; Hermo, L. \& Hess, R. A. Aquaporin-1 and -9 are differentially regulated by oestrogen in the efferent ductule epithelium and initial segment of the epididymis. Biol. Cell, 97(6):385-95, 2005.

Pannabecker, T. L. Aquaporins in desert rodent physiology. Biol. Bull., 229(1):120-8, 2015.

Sellars, M. E. \& Sidhu, P. S. Pictorial review: ultrasound appearances of the rete testis. Eur. J. Ultrasound, 14(2-3):11520, 2001.

Skowronski, M. T. Distribution and quantitative changes in amounts of aquaporin 1, 5 and 9 in the pig uterus during the estrous cycle and early pregnancy. Reprod. Biol. Endocrinol., 8:109, 2010 .

Takei, Y.; Bartolo, R. C.; Fujihara, H.; Ueta, Y. \& Donald, J. A. Water deprivation induces appetite and alters metabolic strategy in Notomys alexis: unique mechanisms for water production in the desert. Proc. Biol. Sci., 279(1738):2599-608, 2012.

Yeung, C. H.; Callies, C.; Tüttelmann, F.; Kliesch, S. \& Cooper, T. G. Aquaporins in the human testis and spermatozoa identification, involvement in sperm volume regulation and clinical relevance. Int. J. Androl., 33(4):629-41, 2010.

Zhou, Q.; Clarke, L.; Nie, R.; Carnes, K.; Lai, L. W.; Lien, Y. H.; Verkman, A.; Lubahn, D.; Fisher, J. S.; Katzenellenbogen, B. S. \& Hess, R. A. Estrogen action and male fertility: roles of the sodium/hydrogen exchanger-3 and fluid reabsorption in reproductive tract function. Proc. Natl Acad. Sci. U. S. A., 98(24):14132-7, 2001.

\author{
Correspondence to: \\ Jianlin Wang \\ School of Life Science \\ Lanzhou university \\ 730000, Lanzhou \\ Gansu \\ CHINA
}

Email:xiaoan314@sohu.com 